\title{
KONTRIBUSI SARANA PRASARANA DAN LINGKUNGAN KERJA NON FISIK TERHADAP MOTIVASI KERJA GURU DI SEKOLAH YAYASAN PENDIDIKAN CENDANA RIAU
}

\author{
Adi Romadona ${ }^{1)}$ \\ Fadly Azhar ${ }^{2)}$ \\ Mahdum 3) \\ 1) Guru SLB Cendana Pekanbaru \\ 2) Lecturer of Education Management Study Programme PPs University of Riau \\ 3) Lecturer of Education Management Study Programme PPS University of Riau \\ Email: adiromadona@gmail.com
}

\begin{abstract}
This study aims to analyze the contribution of independent variables to the dependent variable between infrastructure and non-physical work environment on teacher motivation at the Cendana Education Foundation School. This type of research is quantitative with the causal associative method. Data collection using a questionnaire. The population used in this study were 68 teachers and all of them were examined as respondents (census). The data analysis technique used in this research was descriptive and quantitative analysis (multiple linear regression) by performing the classical assumption test first. The results showed that through the coefficient of determination $(R 2)$, it was known that the variables in infrastructure and non-physical work environments were able to explain the contribution to the teacher work motivation variable by $69.1 \%$. While the remaining $30.9 \%$, influenced by other variables outside of this study. For an $R$ value of 0.831 , it can be interpreted that the correlation coefficient between variables in school infrastructure and non-physical work environments on teacher work motivation is very strong. Meanwhile, infrastructure partially contributes to the work motivation of teachers with a Beta coefficient (standardized coefficient) of 0.524 and an impact test of 0.274. This means that there is a partial contribution of infrastructure to the work motivation of teachers at the Cendana Riau Education Foundation School of 27.4\%. The non-physical work environment partially contributes to teacher work motivation with the Beta coefficient (standardized coefficient) of 0.425 and the impact test of 0.181. This means that there is a partial contribution of infrastructure to the work motivation of teachers at the Cendana Riau Education Foundation School of $18.1 \%$.
\end{abstract}

Keywords: Infrastructure; Non-Physical Work Environment; Teacher Work Motivation 
ABSTRAK

Penelitian ini bertujuan untuk menganalis kontribusi variabel bebas terhadap variabel terikat antara Sarana Prasarana Dan Lingkungan Kerja Non Fisik Terhadap Motivasi Guru Di Sekolah Yayasan Pendidikan Cendana. Jenis Penelitian ini adalah kuantitatif dengan metode asosiatif kausal. Pengumpulan data menggunakan angket. Populasi yang digunakan pada penelitian ini adalah sebanyak 68 orang guru dan semuanya diteliti sebagai responden (sensus). Teknik analisis data penelitian ini menggunakan analisis deskriptif dan kuantitatif (regresi linier berganda) dengan melakukan uji asumsi klasik terlebih dahulu. Hasil penelitian menunjukan bahwa Melalui Koefisien determinasi $\left(\mathrm{R}^{2}\right)$ diketahui secara simultan variabel-variabel pada Sarana prasarana dan lingkungan kerja non fisik mampu menjelaskan kontribusi terhadap variabel motivasi kerja guru sebesar $69,1 \%$. Sedangkan sisanya sebesar 30,9 \%, dipengaruhi oleh variabel lain di luar penelitian ini. Untuk nilai $\mathrm{R}$ sebesar 0,831 dapat diinterpretasikan bahwa koefisien korelasi antara variabel pada Sarana prasarana sekolah dan lingkungan kerja non fisik terhadap motivasi kerja guru adalah sangat kuat. Sementara Sarana prasarana secara parsial berkontribusi terhadap motivasi kerja guru dengan nilai koefisien Beta (standardized coefficient) sebesar 0,524 dan uji pengaruh 0,274. Hal ini berarti terdapat kontribusi sarana prasarana secara parsial terhadap motivasi kerja guru di Sekolah Yayasan pendidikan Cendana Riau sebesar 27,4\%. Lingkungan kerja non fisik secara parsial berkontribusi terhadap motivasi kerja guru dengan nilai koefisien Beta (standardized coefficient) sebesar 0,425 dan uji pengaruh sebesar 0,181. Hal ini berarti terdapat kontribusi sarana prasarana secara parsial terhadap motivasi kerja guru di Sekolah Yayasan pendidikan Cendana Riau sebesar 18,1\%.

Kata Kunci: Sarana Prasarana; Lingkungan Kerja Non Fisik; Motivasi Kerja Guru

\section{PENDAHULUAN}

Motivasi erat kaitannya atau berbanding lurus dengan cita-cita seseorang. Semakin tinggi cita-cita seseorang semakin tinggi pula motivasi dalam dirinya untuk berbuat. Guru yang memiliki motivasi yang tinggi tentu memiliki pola pikir yang berbeda dengan guru yang tanpa motivasi atau motivasi rendah. Hal ini dapat dikatakan bahwa motivasi merupakan perbedaan antara dapat melaksanakan dengan mau melaksanakan. Seseorang yang mengerjakan suatu pekerjaan dengan ikhlas akan berdampak baik pada kinerjanya. Oleh karena itu untuk menjaga kinerja guru agar tetap optimal, perlunya menjaga motivasi dari guru itu sendiri. Seperti memberikan apresiasi kepada guru yang berprestasi, memberikan rasa aman bagi guru tersebut serta memperhatikan sarana prasarana yang memadai sesuai kebutuhan proses pembelajaran dan lingkungan kerja yang mendukung. Karena manusia bekerja tidak sematamata untuk mendapatkan uang, gaji yang tinggi, tidak selalu menjadi faktor tumbuhnya motivasi kerja dalam mencapai produktifitas, tetapi juga untuk memenuhi kebutuhan psikologis dan sosialnya yaitu kebutuhan untuk memperoleh perhatian pada segi kemanusiaannya. Motivasi kerja dapat dipengaruhi oleh beberapa faktor yaitu faktor lingkungan kerja dan faktor hubungan interpersonal.

Menurut Stephen P. Robbins dalam Suwarto (2016) Motivasi ialah kesediaan untuk mengeluarkan tingkat 
upaya yang tinggi ke arah tujuan organisasi, yang dikondisikan oleh kemampuan upaya itu untuk memenuhi sesuatu kebutuhan individual, adapun variabel-variabel yang mempengaruhi motivasi kerja meliputi: upah/gaji, tempat kerja, peralatan kerja, sikap pekerja terhadap pekerjaan, sikap antar teman sejawat/kerja, kepercayaan dan tanggung jawab, kebutuhan untuk meningkatkan kemampuan, kebutuhan untuk berprestasi. Menurut Hamzah B. Uno (2017) motivasi dorongan dasar yang menggerakkan seseorang bertingkah laku. Dorongan ini berada pada diri seseorang yang menggerakkan untuk melakukan sesuatu yang sesuai dengan dorongan dalam dirinya. Motivasi merupakan faktor penggerak yang mempengaruhi tingkah laku manusia. Guru yang memiliki motivasi tinggi dalam pekerjaannya tentu akan terdorong untuk melakukan pekerjaan yang sebaik mungkin secara efektif dan efisien, sehingga tujuan awal guru yang telah direncanakan dapat dilaksanakan dengan baik. Motivasi ini tentunya memiliki kadar yang berbeda-beda setiap individu. Ada yang memiliki motivasi kerja tinggi, rendah dan sedang, semuanya akan berpengaruh terhadap kinerja yang akan dihasilkan.

Berdasarkan dari hasil observasi ke sekolah di lingkungan Yayasan Pendidikan Cendana serta wawancara bersama beberapa unsur pimpinan unit sekolah dan guru, pada bulan Januari 2020 yang lalu terkait motivasi kerja guru di lingkungan Yayasan Pendidikan Cendana, diperoleh keterangan bahwa motivasi kerja guru masih belum optimal atau masih rendah, padahal secara umum sekolah yang berada dalam lingkungan Yayasan Pendidikan Cendana Riau telah memiliki sarana prasarana dan fasilitas belajar yang masih memenenuhi standar pendidikan seperti ruang belajar, perlengkapan belajar dan sarana pendukung lainnya serta memiliki lingkungan kerja yang cukup memadai untuk pendidikan seperti keamanan, kenyamanan dan jauh dari keramaian serta hubungan interpersonal yang tergolong baik. Namun hal ini belum sepenuhnya dapat meningkatkan motivasi kerja pada guru dan pegawai Yayasan Pendidikan Cendana Riau secara optimal.

Keberhasilan seorang guru dalam melaksanakan pembelajaran tidak terlepas dari sarana prasarana dan lingkungan kerja yang kondunsif. Oleh karena itu, setiap guru memerlukan motivasi yang kuat agar bersedia melaksanakan pembelajaran secara bersemangat, bergairah dan berdedikasi sehingga dapat memenuhi kualitas yang diharapkan. Menurut Sedarmayanti (2011) faktor-faktor yang mempengaruhi motivasi antara lain sikap mental, pendidikan, keterampilan, kepemimpinan, tingkat penghasilan, kompensasi, komunikasi, sarana prasarana, kesempatan berprestasi.

Selain faktor sarana dan prasarana sekolah, faktor lain yang mempengaruhi motivasi kerja guru adalah lingkungan kerja. Menurut Lyman Porter dan Raymond Miles dalam Ratna Dewi (2016) menyatakan bahwa ada tiga faktor utama yang berpengaruh terhadap motivasi kerja, yaitu: ciri-ciri pribadi seseorang (induvidual characteristic), tingkat dan jenis pekerjaan (job characteristic) dan lingkungan kerja (work situation characteristic). Ketiga faktor tersebut mempunyai pengaruh besar terhadap motivasi individu dalam mendorong tercapainya produktivitas kerja secara optimal. Kondisi lingkungan kerja yang mendukung sangat dibutuhkan yaitu lingkungan kerja yang nyaman untuk mereka. Lingkungan kerja yang baik akan menfasilitasi mereka untuk kerja lebih baik pula. 
Keberhasilan suatu organisasi tidak terlepas dari faktor lingkungan kerja. Menurut Wursanto (2009) lingkungan kerja non fisik adalah sebagai sesuatu yang menyangkut segi psikis dari lingkungan kerja. Lingkungan kerja non fisik sangat mempengaruhi kepuasan kerja karyawan, dimana jika keadaan atau situasi di sekitar karyawan kondusif untuk bekerja, rekan mudah diajak untuk bekerja sama dan hubungan dengan atasan baik maka karyawan akan menikmati pekerjaannya dan merasa puas bekerja di tempat tersebut. Lingkungan kerja non fisik memberikan kenyamanan tersendiri bagi setiap orang. Kondisi lingkungan kerja yang nyaman dan harmonis akan memberikan kedamaian dan kedekatan atau keakraban antara sesama rekan kerja.

Berdasarkan pendahuluan di atas maka dapat dirumuskan beberapa rumusan masalah pada penelitian ini sebagai berikut: (1) Seberapa besarkah kontribusi sarana prasarana sekolah dan lingkungan kerja non fisik terhadap motivasi kerja guru di Sekolah Yayasan Pendidikan Cendana Riau ? (2) Seberapa Besarkah kontribusi sarana prasarana sekolah terhadap motivasi kerja guru di Sekolah Yayasan Pendidikan Cendana Riau ? (3) Seberapa Besarkah kontribusi lingkungan kerja non fisik terhadap motivasi kerja guru di Sekolah Yayasan Pendidikan Cendana Riau ?. penelitian ini bertujuan tujuan mengetahui dan menganalisis : (1) Kontribusi sarana prasarana sekolah dan lingkungan kerja non fisik terhadap motivasi kerja guru di Sekolah Yayasan Pendidikan Cendana Riau. (2) Kontribusi sarana prasarana sekolah terhadap motivasi kerja guru di Sekolah Yayasan Pendidikan Cendana Riau. (3) Kontribusi lingkungan kerja non fisik terhadap motivasi Kerja guru di Sekolah Yayasan Pendidikan Cendana Riau.

\section{KAJIAN TEORITIS}

\section{Motivasi Kerja Guru}

Hamzah B. Uno (2017) mendefinisikan bahwa motivasi kerja merupakan salah satu faktor yang turut menentukan kinerja seseorang. Motivasi kerja guru tidak lain adalah suatu proses yang dilakukan untuk menggerakkan guru agar perilaku mereka dapat diarahkan pada upayaupaya nyata untuk mencapai tujuan yang telah ditetapkan. Sedangkan menurut Anoraga (2009) motivasi kerja adalah sesuatu yang menimbulkan semangat atau dorongan kerja. Dorongan ini bisa internal maupun eksternal, serta bisa kuat dan lemah. Sehingga motivasi merupakan suatu model dalam menggerakkan dan mengarahkan para guru agar dapat melaksanakan tugasnya dalam mencapai sasaran/tujuan yang telah ditetapkan dengan penuh kesadaran dan penuh tanggug jawab. Senada dengan pendapat Anoraga, menurut Siagian (2012) motivasi adalah daya pendorong yang mengakibatkan seseorang anggota organisasi mau dan rela untuk mengerahkan kemampuan dalam bentuk keahlian atau keterampilan, tenaga dan waktunya untuk menyelenggarakan berbagai kegiatan yang menjadi tanggung jawabnya dan menunaikan kewajibannya dalam rangka pencapaian tujuan dan berbagai sasaran organisasi yang telah ditentukan sebelumnya.

Malayu S.P Hasibuan dalam Trias Fenanti (2015) menyebutkan beberapa tujuan motivasi kerja yaitu: (1) Meningkatkan moral dan kepuasan kerja karyawan, (2) Meningkatkan produktivitas 
karyawan, (3) Mempertahankan kestabilan karyawan perusahaan, (4) Meningkatkan kedisiplinan karyawan, (5) Mengefektifkan pengadaan karyawan, Menciptakan suasana dan hubungan kerja yang baik, (7) Meningkatkan loyalitas, kreativitas, dan partisipasi karyawan, (8) Meningkatkan tingkat kesejahteraan karyawan,

Mempertinggi rasa tanggung jawab karyawan terhadap tugas-tugasnya, (10) Meningkatkan efisiensi penggunaan alat-alat dan bahan baku.

Menurut Hamzah B. Uno (2017) yang membagi dimensi dan indikator motivasi kerja menjadi 2 kelompok, yaitu : (1) Dimensi Motivasi internal yang terdiri dari : (a) Tanggung jawab guru dalam melaksanakan tugas,

Melaksanakan tugas dengan target yang jelas, (c) Memiliki tujuan yang jelas dan menantang, (d) Ada umpan balik atas hasil pekerjaannya, (e) Memiliki perasaan senang dalam bekerja, (f) Selalu berusaha untuk mengungguli orang lain, (g) Diutamakan prestasi dari apa yang dikerjakannya. (2) Dimensi Motivasi Ekstrnal yang terdiri dari : (a) Selalu berusaha untuk memenuhi kebutuhan hidup dan kebutuhan kerjanya, (b) Senang memperoleh pujian dari apa yang dikerjakannya, (c) Bekerja dengan harapan ingin memperoleh insentif, (d) Bekerja dengan harapan ingin memperoleh perhatian dari teman dan atasan.

$$
\text { Menurut Sedarmayanti }
$$

(2017) menyatakan ada beberapa faktor motivasi dan pemeliharaan lingkungan pekerjaannya yaitu ada enam faktor motivasi yakni: (1) prestasi, (2) pengakuan, kemajuan/kenaikan pangkat, (4) pekerjaan itu sendiri, kemungkinan untuk tumbuh, (6) tanggung jawab. Sedangkan untuk pemeliharaan terdapat sepuluh faktor yang perlu diperhatikan, yaitu: (1) kebijaksanaan, (2) supervisi teknis, (3) hubungan antar manusia dan atasan, (4) hubungan manusia dengan pembinanya, (5) hubungan manusia dengan bawahannya, (6) gaji dan upah, (7) kestabilan kerja, (8) kehidupan pribadi, (9) kondisi tempat kerja, (10) status.

\section{Sarana Prasana}

Sarana

pendidikan merupakan sarana penunjang bagi proses belajar mengajar. Sarana pendidikan adalah semua fasilitas yang diperlukan dalam proses belajar mengajar baik yang bergerak maupun tidak bergerak agar pencapaian tujuan pendidikan dapat berjalan dengan lancar, teratur, efektif dan efesien. Menurut Imam Gunawan (2017) Sarana adalah perlengkapan yang secara langsung digunakan dalam proses pendidikan dan keberadaanya tidak dapat digantikan. Sedangkan Prasarana adalah perlengkapan yang secara tidak langsung digunakan dalam proses pendidikan dan keberadaanya dapat digantikan. Hal senada juga dikemukakan oleh Nurabadi (2014) yang menyatakan sarana pendidikan mencakup semua peralatan dan perlengkapan yang secara langsung digunakan dan menunjang dalam proses pendidikan, seperti gedung, ruang belajar, alat pendidikan, meja dan kursi. Sedangkan Prasarana pendidikan adalah fasilitas yang secara tidak langsung menunjang jalannya proses pendidikan seperti halaman, kebun, taman dan jalan menuju sekolah.

Menurut Aunurrahman dalam

Anisa Rahmatul Karim, (2019) 
Pengukuran variabel Sarana dan Prasarana meliputi 6 indikator sebagai berikut yaitu : (1). Penataan gedung sekolah; (2). Kuantitas dan kualitas ruang kelas; (3). Keberfungsian fasilitas kelas dan laboraturium (4). Keberfungsian fasilitas perpustakaan; (5). Ketersediaan buku-buku pelajaran; (6). Optimalisasi media/alat bantu.

\section{Lingkungan Kerja Non Fisik}

Di dalam lingkungan kerja tidak hanya memperhatikan dari segi lingkungan fisik saja, akan tetapi lingkungan kerja non fisik merupakan salah satu hal yang penting dalam meningkatkan efektivitas kerja guru. Karena lingkungan kerja fisik maupun lingkungan kerja non fisik dapat mempengaruhi fisik dan psikis guru dalam bekerja.

Menurut Sedarmayanti dalam Virgiyanti dan Bambang Swasto Sunuharyo (2018), lingkungan kerja terbagi menjadi dua yaitu lingkungan kerja fisik berupa aset fisik yang dimiliki perusahaan dan lingkungan kerja non fisik yang merupakan bagian dari lingkungan kerja keseluruhaan yang didalamnya mencangkup hal-hal seperti perilaku orang-orang yang berada dalam organisasi. Lingkungan kerja non fisik ini tidak kalah pentingnya dengan lingkungan kerja fisik. Lebih lanjut dijelaskan oleh Sedarmayanti (2011) menyatakan lingkungan kerja non fisik adalah "semua keadaan yang terjadi yang berkaitan dengan hubungan kerja, baik hubungan dengan atasan maupun hubungan sesama rekan kerja, ataupun hubungan dengan bawahan".

Menurut $\begin{array}{r}\text { Mangkunegara } \\ \text { (2004) ada beberapa faktor } \\ \text { ingkungan kerja non fisik yaitu: (1) }\end{array}$

Faktor Lingkungan Sosial, lingkungan sosial yang sangat berpengaruh terhadap kinera karyawan adalah latar belakang keluarga, yaitu antara lain status keluarga, jumlah keluarga, tingkat keseahteraan dan lain-lain. (2) Faktor Status Sosial, semakin tinggi jabatan seseorang semakin tinggi pula kewenangan dan keleluasaan dalam mengambil keputusan. (3) Faktor Hubungan Kerja Dalam organisasi, hubungan kerja yang ada dalam organisasi adalah hubungan kerja antara guru dengan guru dan antara guru dengan atasan. (4) Faktor Sistem Informasi, hubungan kerja akan dapat berjalan dengan baik apabila ada komunikasi yang baik antara anggota organisasi. Dengan adanya komunikasi dilingkungan kerja maka anggota organisasi akan berinteraksi, saling memahami, saling mengerti satu sama lain dapat menghilangkan perselisihan salah paham.

\section{METODOLOGI PENELITIAN}

Pendekatan penelitian yang digunakan dalam penelitian ini menggunakam jenis penelitian Kuantitatif. Penelitian kuantitatif dapat diartikan sebagai jenis penelitian yang berlandasan pada filsafat positivisme digunakan untuk meneliti pada populasi atau sempel tertentu, pengumpulan data menggunakan instrument penelitian, analisis data bersifat kuantitatif/stastistik, dengan tujuan untuk menguji hipotesis yang telah ditetapkan (Sugiyono: 2018). Sedangkan metode penelitian yang digunakan dalam penelitian ini menggunakan metode asosiatif kausal. metode asosiatif kausal merupakan suatu penelitian yang mencari hubungan sebab akibat antara variabel independen (variabel bebas) dengan variabel 
dependen (variabel terikat) (Sugiyono : 2018). Penelitian ini akan menguji kontribusi antara variable sarana prasarana $\left(\mathrm{X}_{1}\right)$ dan lingkungan kerja non fisik $\left(\mathrm{X}_{2}\right)$ terhadap motivasi kerja (Y).

Penelitian ini dilakukan di Sekolah di bawah naungan Yayasan Pendidikan Cendana Riau distrik Rumbai yang terletak di Komplek PT. Chevron Pacific Indonesia (CPI) Rumbai Pesisir Kota Pekanbaru Riau Indonesia. Sekolah tersebut terdiri dari jenjang PAUD, SLB, SD, SMP dan SMA. Populasi dari penelitian ini adalah guru-guru di lingkungan Yayasan Pendidikan Cendana Riau wilayah kerja Peknabaru yang berjumlah sebanyak 68 orang dan semua diteliti dijadikan responden.

Teknik pengumpulan data yang digunakan untuk mendapatkan data yang di perlukan sesuai dengan tujuan penelitian adalah dengan instrumen Angket (kuisioner). Angket yang digunakan merupakan angket tertutup, yaitu dalam setiap butir pertanyaan telah tersedia jawaban. Penyusunan instrumen penelitian ini dilakukan melalui beberapa tahap, yaitu (1) menentukan variabel yang akan diteliti dan indikator penelitian, (2) membuat kisi - kisi angket, (3) menyusun butir pernyataan berdasarkan indikator yang telah ditetapkan dari kedua variabel penelitian sesuai dengan kebutuhan yang dibuat dengan berpedoman pada indikator masing - masing variabel, (4) mengkonsultasikan angket tersebut dengan pembimbing, (5) melakukan uji coba angket responden diluar sampel penelitian, (6) menganalisis data hasil ujicoba untuk melihat validitas dan reliabilitas angket.

Teknik Analisis data yang digunakan adalah teknik analisis deskriptif dan kuantitatif (regresi linier berganda). Bertujuan untuk mengetahui pengaruh atau hubungan secara linier antara variabel independen terhadap variabel dependen dan untuk memprediksi atau meramalkan suatu nilai variabel dependen berdasarkan variabel independen. Di dalam model regresi ini, ada beberapa syarat yang harus dipenuhi agar model peramalan yang dibuat menjadi valid sebagai alat peramalan. Syarat-syarat tersebut apabila dipenuhi semuanya, maka model regresi linear tersebut dikatakan BLUE (Best Linear Unbiased Estimation). Sebelum melakukan analisis regresi linier berganda terlebih dahulu dilakukan uji asumsi klasik dengan pengolahan data menggunakan aplikasi SPSS versi 19, yang terdiri dari (1) Uji Normalitas, (2) Uji Linieritas, (3) Uji Multikolinearitas, (4) Uji Heteroskedastisitas.

\section{HASIL PENELITIAN DAN PEMBAHASAN}

\section{1) Analisis Deskriptif Variabel Penelitian}

Analisis Deskriptif Variabel Penelitian ini adalah untuk menjelaskan secara umum gambaran data variabel yang diperoleh dari pengumpulan data terkait Variabelvariabel penelitian ini :

Tabel 1 : Analisis Deskriptif Variabel Penelitian

\begin{tabular}{ccccccc}
\hline Variabel & N & Mean & Median & Min & Max & $\begin{array}{c}\text { Standard } \\
\text { Deviation }\end{array}$ \\
\hline $\begin{array}{c}\text { Motivasi } \\
\text { Kerja Guru }\end{array}$ & 68 & 103,75 & 104,00 & 97 & 110 & 3,401 \\
\hline
\end{tabular}




\begin{tabular}{ccccccc}
\hline $\begin{array}{c}\text { Sarana } \\
\text { Prasarana }\end{array}$ & 68 & 102,00 & 102,00 & 94 & 110 & 3,761 \\
$\begin{array}{c}\text { Lingkungan } \\
\text { Kerja Non } \\
\text { Fisik }\end{array}$ & 68 & 100,71 & 101,00 & 92 & 110 & 4,675 \\
\hline
\end{tabular}

a) Motivasi Kerja Guru

Pengumpulan data variabel motivasi kerja guru didapat dari penyebaran angket sebanyak 68 orang responden. Skor motivasi kerja guru menyebar dari skor terendah 97 sampai skor tertinggi 110. Dari hasil pengolahan data secara umum, maka motivasi kerja guru diperoleh skor mean 103,75; median 104,00 ; dan standar deviasi 3,401. Hasil pengolahan data variabel motivasi kerja guru dengan membandingkan skor rata-rata dengan skor maksimal dikali $100 \%$, maka 103,75 dibagi 110 dikali $100 \%$ dapat diketahui bahwa motivasi kerja guru berada pada skor $94,3 \%$.

b) Sarana Prasarana

Pengumpulan data variabel sarana prasarana didapat dari penyebaran angket sebanyak 68 orang responden. Skor sarana prasarana menyebar dari skor terendah 94 sampai skor tertinggi 110. Dari hasil pengolahan data secara umum, maka sarana prasarana diperoleh skor mean 102,00; median 102,00 ; dan standar deviasi 3,761. Hasil pengolahan data variabel sarana prasarana dengan membandingkan skor rata-rata dengan skor maksimal dikali $100 \%$, maka 102,00 dibagi 110 dikali $100 \%$, dapat diketahui bahwa sarana prasarana berada pada skor $92,7 \%$.

c) Lingkungan Kerja Non Fisik

Pengumpulan data variabel lingkungan kerja non fisik didapat dari penyebaran angket sebanyak 68 orang responden. Skor lingkungan kerja non fisik menyebar dari skor terendah 92 sampai skor tertinggi 110. Dari hasil pengolahan data secara umum, maka lingkungan kerja non fisik diperoleh skor mean 100,71; median 101,00 dan standar deviasi 4,675. Hasil pengolahan data variabel lingkungan kerja non fisik dengan membandingkan skor rata-rata dengan skor maksimal dikali $100 \%$, maka 100,71 dibagi 110 dikali 100\%, dapat diketahui bahwa lingkungan kerja non fisik berada pada skor $91,6 \%$.

\section{2) Pengujian Hipotesis Penelitian}

Analisis data menggunakan Analisis regresi linier berganda digunakan untuk mengetahui pengaruh atau hubungan secara linear antara dua atau lebih variabel independen dengan satu variabel dependen. Berikut akan dilakukan analisis regresi linier berganda untuk mengetahui pengaruh antara variabel Sarana Prasarana $\left(\mathrm{X}_{1}\right)$ dan Lingkungan Kerja $\left(\mathrm{X}_{2}\right)$ terhadap Motivasi Kerja Guru (Y). 
Tabel 2 : Hasil Analisis Regresi Berganda

\begin{tabular}{|c|c|c|c|c|}
\hline \multirow{2}{*}{ Variabel } & \multicolumn{2}{|c|}{$\begin{array}{c}\text { Unstandardizer } \\
\text { Coefficients }\end{array}$} & \multirow{2}{*}{$\begin{array}{c}\begin{array}{c}\text { Standardizer } \\
\text { Coefficients }\end{array} \\
\text { Beta }\end{array}$} & \multirow{2}{*}{$\begin{array}{l}\text { Pengaruh } \\
{(\text { Beta })^{2}}^{\text {Pen }}\end{array}$} \\
\hline & B & $\begin{array}{l}\text { Std. } \\
\text { Error }\end{array}$ & & \\
\hline (Constant) & 23,623 & 6,735 & & \\
\hline $\begin{array}{c}\text { Sarana } \\
\text { Prasarana }\end{array}$ & 0,480 & 0,075 & 0,524 & 0,274 \\
\hline $\begin{array}{c}\text { Lingkungan } \\
\text { Kerja Non } \\
\text { Fisik }\end{array}$ & 0,309 & 0,059 & 0,425 & 0,181 \\
\hline
\end{tabular}

*Dependent Variable : Motivasi Kerja Guru

Berdasarkan analisis data dengan menggunakan SPSS 19, diperoleh hasil persamaan regresi sebagai berikut :

$$
Y=23,623+0,480 X_{1}+0,309 X_{2}
$$

Persamaan regresi diatas memperlihatkan hubungan antar variabel independen dengan variabel dependen secara parsial. Dari persamaan tersebut dapat diambil kesimpulan bahwa :

a) Nilai constanta adalah 23,623, artinya jika tidak terjadi perubahan variabel sarana prasarana $\left(\mathrm{X}_{1}\right)$ dan lingkungan kerja $\left(X_{2}\right)$, Nilai $X_{1}$ dan $X_{2}$ adalah 0 (nol), maka motivasi kerja guru adalah sebesar 23,623.

b) Nilai koefisien regresi variabel Sarana Prasarana bernilai positif yaitu 0,480 , ini dapat diartikan jika setiap peningkatan Sarana Prasarana sebesar 1 satuan, maka akan meningkatkan Motivasi Kerja Guru sebesar 0,480 satuan dengan asumsi variabel independen lain nilainya tetap. Hal tersebut menunjukkan bahwa variabel sarana prasarana yang disediakan berkontribusi positif bagi motivasi kerja guru, sehingga semakin komplet sarana prasarana yang disediakan maka meningkat pula motivasi kerja guru.

c) Nilai koefisien regresi variabel lingkungan kerja bernilai positif yaitu 0,309 , ini dapat diartikan jika setiap peningkatan Lingkungan Kerja sebesar 1 satuan, maka akan meningkatkan motivasi kerja guru sebesar 0,309 satuan dengan asumsi variabel independen lain nilainya tetap. Hal tersebut menunjukkan bahwa variabel lingkungan kerja yang disediakan berkontribusi positif bagi motivasi kerja guru, sehingga semakin kondunsif lingkungan kerja, maka meningkat pula motivasi kerja guru.

d) Secara parsial terdapat kontribusi positif antara sarana prasarana $\left(\mathrm{X}_{1}\right)$ terhadap motivasi kerja guru (Y) di Sekolah Yayasan Pendidikan

Cendana 
berdasarkan Standardizer Coefficients Beta sebesar $\mathrm{r}_{\mathrm{x} 1 \mathrm{y}}{ }^{2}=$ 0,524 , ini bermakna bahwa 27,4 $\%$ motivasi kerja guru dapat ditentukan oleh sarana prasarana. Ini menunjukkan bahwa secara parsial sarana prasarana dapat memberikan kontribusi terhadap motivasi kerja guru di Sekolah Yayasan Pendidikan Cendana Riau sebesar $27,4 \%$.

e) Secara parsial terdapat kontribusi positif antara lingkungan kerja non fisik $\left(\mathrm{X}_{2}\right)$ terhadap motivasi kerja guru (Y) di Sekolah Yayasan Pendidikan Cendana Riau berdasarkan Standardizer Coefficients Beta sebesar $r_{x 2 y}{ }^{2}=0,425$, ini bermakna bahwa 18,1 \% motivasi kerja guru dapat ditentukan oleh lingkungan kerja non fisik. Ini menunjukkan bahwa secara parsial lingkungan kerja non fisik $\left(\mathrm{X}_{2}\right)$ dapat memberikan kontribusi terhadap motivasi kerja guru di Sekolah Yayasan Pendidikan Cendana Riau sebesar 18,1\%.

f) Secara simultan terdapat kontribusi positif sarana prasarana dan lingkungan kerja non fisik terhadap motivasi kerja guru di Sekolah Yayasan Pendidikan Cendana Riau, hal ini dapat dilihat pada tabel berikut :

Tabel 4.6 : Hasil Analisis Secara Simultan kontribusi Sarana Prasarana dan Lingkungan Kerja Non Fisik terhadap Motivasi Kerja guru

\begin{tabular}{ccc}
\hline Model & F & Sig \\
\hline Regression & 72,649 & 0,000 \\
\hline
\end{tabular}

- $\quad$ Predictors ; (Constant), Lingkungna Kerja Non Fisik, Sarana Prasarana

- Dependent Variabel : Motivasi Kerja Guru

Berdasarkan tabel 4.6 diatas diperoleh $F$ hitung sebesar 72,649 dan nilai Signifikansi sebesar 0,000. Jadi dapat disimpulkan bahwa secara bersama-sama (simultan) sarana prasarana sekolah dan lingkungna kerja non fisik berkontribusi terhadap motivasi kerja guru di Sekolah Yayasan Pendidikan Cendana Riau. g) Koefisien determinasi $\left(\mathrm{R}^{2}\right)$ untuk mengukur kemampuan model dalam menerangkan variasi variabel dependen. Nilai $R^{2}$ adalah antara 0 dan 1 . Nilai $R$ square mendekati 1 berarti variabel-variabel independen memberikan hampir semua informasi yang dibutuhkan untuk memprediksi variasi variabel dependen berdasarkan uji $\mathrm{R}^{2}$ yang dilakukan.

Tabel 3 : Hasil Analisis Koefisien Determinan $\left(\mathbf{R}^{2}\right)$

\begin{tabular}{ccc}
\hline Model & $\mathbf{R}$ & R Square \\
\hline 1 & $\mathbf{0 , 8 3 1}$ & $\mathbf{0 , 6 9 1}$
\end{tabular}

- $\quad$ Predictors ; (Constant), Lingkungna Kerja Non Fisik, Sarana Prasarana 
Berdasarkan tabel 3 di atas, hasil analisis korelasi dari output regresi yang mengkorelasi pengaruh variabel-variabel bebas terhadap motivasi kerja guru (Y) diperoleh nilai $\mathrm{R}^{2}=0,691$ menunjukkan bahwa secara simultan variabelvariabel pada Sarana prasarana dan lingkungan kerja non fisik mampu menjelaskan pengaruhnya atau kontribusi terhadap variabel motivasi kerja guru sebesar $69,1 \%$. Sedangkan sisanya sebesar $30,9 \%$, dijelaskan atau dipengaruhi oleh variabel lain di luar penelitian ini. Untuk nilai $R$ sebesar 0,831 dapat diinterpretasikan bahwa koefisien korelasi antara variabel fokus pada Sarana prasarana sekolah dan lingkungan kerja non fisik terhadap motivasi kerja guru adalah sangat kuat ( Sugiyono, 2018).

Untuk lebih jelasnya dapat dilihat pada gambar pola pengaruh antar variabel sebagai berikut :

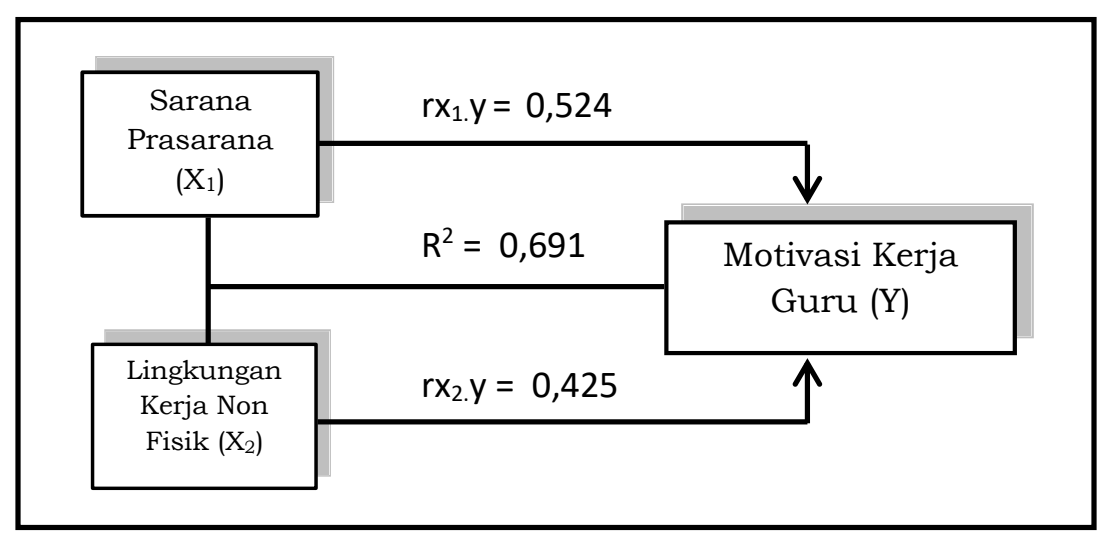

Gambar 1 : Pola Pengaruh Sarana Prasarana dan Lingkungan Kerja Non Fisik terhadap Motivasi Kerja Guru

1) Kontribusi Sarana Prasarana dan Lingkungan Kerja Non Fisik Terhadap Motivasi Kerja Guru

Hasil penilitian menunjukkan bahwa hasil analisis korelasi dari output regresi yang mengkorelasi pengaruh variabel-variabel bebas terhadap motivasi kerja guru (Y) diperoleh nilai $\mathrm{R}^{2}=0,691$ secara simultan variabel sarana prasarana dan lingkungan kerja non fisik mampu menjelaskan pengaruhnya atau kontribusi terhadap variabel motivasi kerja guru sebesar $69,1 \%$. Sedangkan sisanya sebesar 30,9\%, dijelaskan atau dipengaruhi oleh variabel lain di luar penelitian ini. Untuk nilai $\mathrm{R}$ sebesar 0,831 dapat diinterpretasikan bahwa koefisien korelasi antara variabel fokus pada Sarana prasarana dan lingkungan kerja non fisik terhadap motivasi kerja guru adalah sangat kuat.

Hal ini sejalan dengan penelitian yang dilakukan oleh Elsa Putri Widyasari (2019) bahwa variabel Lingkungan Kerja $\left(X_{1}\right)$, Sarana Prasarana $\left(\mathrm{X}_{2}\right)$, dan Insentif $\left(\mathrm{X}_{3}\right)$ secara bersama-sama (simultan) memiliki pengaruh yang signifikan terhadap Motivasi Kerja (Y) pada karyawan di PT. Matahari Putra Prima, Tbk Cabang Surabaya. Hal ini dapat dilihat dengan $F_{\text {hitung }}$ sebesar 28.076 dengan nilai signifikan sebesar 0,000, yang lebih 
kecil dari $\alpha(0,05)$, maka dapat disimpulkan Ho ditolak dan $\mathrm{Ha}$ diterima. Dengan demikian dari hasil uji F (simultan) diperoleh keterangan bahwa dalam Motivasi Kerja perlu adanya Lingkungan Kerja, Sarana Prasarana, dan Insentif agar terciptanya rasa nyaman dalam bekerja sehingga tujuan perusahaan dapat tercapai. Dari hasil tersebut maka dapat diambil suatu kesimpulan pada hipotesis pertama yang menyatakan bahwa variabel yaitu Lingkungan Kerja $\left(\mathrm{X}_{1}\right)$, Sarana Prasarana $\left(\mathrm{X}_{2}\right)$, dan Insentif $\left(\mathrm{X}_{3}\right)$ secara bersamasama (simultan) memiliki pengaruh terhadap Motivasi Kerja (Y) pada karyawan PT. Matahari Putra Prima, Tbk Cabang Surabaya.

Berdasarkan hasil penelitian yang dikemukakan di atas maka secara bersama-sama atau simultan dapat dikatakan bahwa sarana prasarana dan lingkungan kerja non fisik mempunyai kontribusi terhadap motivasi kerja guru di sekolah Yayasan Pendidikan Cendana Riau. Oleh karena itu pentingnya sarana prasarana yang baik dan dapat digunakan dalam melaksanakan pekerjaan dan pembelajaran sedangkan lingkungan kerja non fisik harus selalu diperhatikan agar tetap terjaga kenyamanan dan keharmonisannya. Lingkungan kerja yang baik tentunya akan dapat menciptakan suasana yang nyaman bagi guru dan tenaga kependidikan lainya untuk bekerja dan beraktivitas sehingga akan dapat meningkatkan kinerja organisasi secara keseluruhan.

\section{2) Kontribusi Sarana Prasarana terhadap Motivasi Kerja Guru}

Hasil penelitian menunjukan bahwa sarana prasarana secara parsial berkontribusi terhadap motivasi kerja guru dengan nilai koefisien Beta (standardized coefficient) sebesar 0,524 dan uji pengaruh 0,274. Hal ini berarti terdapat kontribusi sarana prasarana secara parsial terhadap motivasi kerja guru di Sekolah Yayasan pendidikan Cendana Riau sebesar $27,4 \%$.

Penelitian ini sejalan dengan penelitian yang dilakukan oleh Bohari, Ansar dan Muhammad Tamrin (2019) Berdasarkan hasil penelitian dapat dilihat bahwa sarana prasarana berpengaruh positif dan signifikan terhadap motivasi kerja. Hal ini dapat dilihat dari hasil koefisien jalur bernilai positif sebesar 0,274 serta nilai thitung sebesar 2,534 dengan signifikan pada $0,013<0,05$. Olehnya itu, implikasinya adalah jika sarana prasarana kerja semakin baik, maka petugas kebersihan pada Dinas Lingkungan Hidup dan Kehutanan Kabupaten Bulukumba akan memiliki motivasi kerja yang semakin tinggi pula, sebaliknya jika sarana prasarana kerja semakin buruk, maka motivasi kerja petugas kebersihan juga akan semakin rendah.

Ketika kelengkapan sarana prasarana pendidikan secara parsial memberikan kontribusi terhadap motivasi kerja guru, maka tugas guru dalam menyampaikan materi pelajaran akan mampu terlaksana secara maksimal sehingga kinerja guru secara otomatis akan meningkat. Karena kelengkapan sarana prasarana pendidikan merupakan salah satu yang mempengaruhi motivasi kerja guru. Oleh karena itu harus diperhatikan 
ketersediaan dan pengelolannya secara baik. Sebab sarana dan prasarana pendidikan dapat menjadi pendukung faktor-faktor lain yang lebih dominan dan mampu membuat motivasi kerja guru dapat meningkat.

\section{3) Kontribusi Lingkungan Kerja Non Fisik dengan Motivasi Kerja Guru}

Hasil penelitian menunjukan bahwa lingkungan kerja non fisik secara parsial berkontribusi terhadap motivasi kerja guru dengan nilai koefisien Beta (standardized coefficient) sebesar 0,425 dan uji pengaruh sebesar 0,181. Hal ini berarti terdapat kontribusi sarana prasarana secara parsial terhadap motivasi kerja guru di Sekolah Yayasan pendidikan Cendana Riau sebesar $18,1 \%$.

Penelitian ini sejalan dengan yang dikemukakan oleh Ratna Dewi (2016) yang berjudul Pengaruh Lingkungan Kerja dan Hubungan Interversonal Terhadap Motivasi Kerja Guru SD Negeri Gugus Empat Kecamatan Senapelan Kota Pekanbaru. Berdasarkan hasil penelitian dapat dilihat bahwa terdapat pengaruh positif antara lingkungan kerja $\left(\mathrm{X}_{1}\right)$ terhadap motivasi kerja (Y) guru SD Negeri Gugus Empat Kecamatan Senapelan sebesar $\mathrm{r}_{\mathrm{y} 1}^{2}=$ 0,295, maknanya ini menunjukkan bahwa 8,7 \% motivasi kerja dapat ditentukan oleh lingkungan kerja, Artinya motivasi kerja dapat ditingkatkan melalui lingkungan kerja. Pengaruh yang demikian juga berarti bahwa motivasi kerja dapat ditelusuri, dijelaskan, atau bahkan diramalkan dari lingkungan kerja.

Lingkungan kerja non fisik ini tidak kalah pentingnya dengan lingkungan kerja fisik. Motivasi kerja guru sangat dipengaruhi oleh keadaan lingkungan kerja non fisik, misalnya hubungan dengan sesama guru dan dengan pemimpinnya. Lingkungan kerja non fisik merupakan segala suatu yang penting yang dilakukan atasan, bawahan maupun sesama rekan kerja untuk saling berkomunikasi atau bekerjasama dengan baik, dan saling menghormati agar terciptanya keharmonisan antar pekerja.

\section{SIMPULAN}

Berdasarkan hasil penelitian ini, maka dapat dsimpulkan sebagai berikut: (1) Sarana prasarana dan lingkungan kerja non fisik secara simultan berkontribusi terhadap motivasi kerja guru di Sekolah Yayasan Pendidikan Cendana Riau dengan nilai pengaruh sebesar 69,1 \%. (2) Sarana prasarana secara parsial berkontribusi terhadap motivasi kerja guru di Sekolah Yayasan Pendidikan Cendana Riau dengan nilai pengaruh sebesar 27,4\%. Lingkungan kerja non fisik secara parsial berkontribusi terhadap motivasi kerja guru di Sekolah Yayasan Pendidikan Cendana Riau dengan nilai pengaruh sebesar $18,1 \%$.

Berdasarkan kesimpulan diatas, maka saran yang dapat diberikan dalam penelitian ini adalah sebagai berikut: (1) Sarana prasarana berkontribusi positif dan signifikan terhadap motivasi kerja guru, oleh karena itu perlu ada manajemen sarana prasarana memadai terutama dalam perencanaan, pengadaan, pemamfaatan dan pemeliharaaan, sehingga sarana prasarana dapat lebih efektif dan efisien dalam mencapai tujuan pendidikan terutama mewujudkan visi dan misi yayasan. (2) Lingkungan kerja non fisik memberi pengaruh siknifikan terhadap 
motivasi kerja guru, untuk itu dapat menjadi pertimbangan dalam membuat kebijakan dan memfasilitasi serta membuat wadah bagi guru dan karyawan dalam berinteraksi sosial di lingkungan yayasan seperti olahraga bersama dan lain sebagainya. (3) Penelitian ini masih bersifat umum, karena masih banyak faktor dan variabel lain yang mempengaruhi motivasi kerja guru, maka penulis menyarankan bagi peneliti selanjutnya untuk menggunakan variabel lain selain variabel dalam penelitian ini untuk diteliti pada masa yang akan datang.

\section{UCAPAN TERIMA KASIH}

Pada akhirnya, penulis menyadari bahwaartikel ini tidak akan selesai tanpa dukungan dari rekanrekan majelis guru SLB Cendana atas segala bantuan dan dukungan yang telah diberikan.

\section{DAFTAR PUSTAKA}

Anoraga, Panji, 2009, Psikologi Kerja, Rineka Cipta, Jakarta.

Bohari, Ansar Dan Muhammad Tamrin, 2019, Pengaruh Kompensasi, Sarana Prasarana Melalui Motivasi Kerja Terhadap Kinerja Petugas Kebersihan Pada Dinas Lingkungan Hidup Dan Kehutanan Kabupaten Bulukumba :Yume Journal Of Management volume 2 No. 3 2019

Dewi, Ratna, Isjoni dan Hadriana, 2016, Pengaruh Lingkungan Kerja Dan Hubungan Interpersonal Terhadap Motivasi Kerja Guru Gugus Empat Kecamatan Senapelan,
Jurnal Manajemen Pendidikan ISSN 2338-5278, Program Studi Magister Administrasi Pendidikan Program Pascasarjana Universitas Riau.

Fenanti, Trias, 2015. Hubungan Lingkungan Kerja Non Fisik dan Motivasi Kerja terhadap Kepuasan Kerja Guru SMA Negeri di Kabupaten Sleman Yogyakarta, Skripsi, Universitas Negeri Yogyakarta.

Ghozali, Imam , 2016, “Aplikasi Analisis Multivariate Dengan Program SPSS'. Badan Penerbit Universitas Diponegoro, Semarang.

Gunawan, Imam dan Djum Djum Noor Benty, 2017. Manajemen Pendidikan, Suatu Pengantar Praktik, Alfabeta, Bandung.

Karim, Anisa Rahmatul, 2019, Pengaruh Pemanfaatan Sarana Terhadap Efektivitas Pembelajaran Pendidikan Agama Islam Di Smp Negeri 2 Tarik Sidoarjo, Skripsi, Program Studi Manajemen Pendidikan Islam Jurusan Pendidikan Islam Fakultas Tarbiyah Dan Keguruan Universitas Islam Negeri Sunan Ampel Surabaya

Mangkunegara, AA dan Anwar Prabu, 2004, Perilaku dan Budaya Organisasi, Refika Aditama, Bandung.

Nurabadi, A, 2014, Manajemen Sarana dan Prasarana Pendidikan, Jurusan Administrasi Pendidikan Fakultas Ilmu 
Pendidikan Universitas Negeri Malang.

Pangarso, Astadi dan Vidi Ramadhyanti, 2015, Pengaruh Lingkungan Kerja Non Fisik Terhadap Kepuasan Kerja Dosen Tetap Studi Pada Fakultas Komunikasi Dan Bisnis Universitas Telkom Bandung, dalam Jurnal Kinerja, Volume 19, No.1, Th. 2015: Hal. 172-191, Universitas Telkom Bandung.

Sedarmayanti, 2017, Manajemen Sumber Daya Manusia. Refika Aditama. Bandung. ,2011, Tata Kerja dan Produktifitas Kerja, Penerbit Mandar Maju, Bandung.

Siagian, Sondang P, 2012, Teori Motivasi dan Aplikasinya, Rineka Cipta, Jakarta.

Sugiyono, 2018, Metode Penelitian Manajemen, CV. Alfabeta, Bandung.

Suwarto, FX., 2016, Analisis VariabelVariabel Yang Mempengaruhi Motivasi Kerja Pada Koperasi Persatuan Pedagang Kaki Lima Yogyakarta (KPPKLY), Jurnal Manajemen/Volume XXI, No. 02, Juni 2016: 255-269 :
Fakultas Ekonomi Universitas Atma Jaya Yogyakarta.

Swasto, Bambang, 2011, Manajemen Sumber Daya Manusia, UB Press. Malang

Uno, Hamzah B, 2017, Teori Motivasi dan Pengukurannya, Remaja Rosdakarya Offset, Bandung

Virgiyanti dan Bambang Swasto Sunuharyo, 2018. Pengaruh Lingkungan Kerja Fisik Dan Non Fisik Terhadap Kinerja Karyawan (Studi Pada Karyawan Divisi Fresh Pt. Trans Retail Indonesia (Carrefour) PlazaTangerang City) Jurnal Administrasi Bisnis (JAB)|Vol. 61 No. 2 Agustus 2018| 55-60 Fakultas Ilmu Administrasi, Universitas Brawijaya Malang.

Widyasari, Elsa Putri ,2019, Pengaruh Lingkungan Kerja, Sarana Prasarana Dan Insentif Terhadap Motivasi Kerja Karyawan Pt. Matahari Putra Prima,Tbk Cabang Surabaya, Skripsi : Fakultas Ekonomi Dan Bisnis Universitas Bhayangkara Surabaya.

Wursanto, 2009, Dasar-Dasar Ilmu Organisasi, Andi Offset, Yogyakarta. 